\title{
Uncertainty among the Migrants during the Lockdown in India
}

\author{
Neetu Jha
}

\begin{abstract}
COVID-19 pandemic is a global health crisis that has put the entire world economy at a halt. The impact of COVID-19 has gone beyond public health to social and economic issues, especially for migrant workers. To tackle the spread of COVID-19 virus, as many other countries the Indian government has also implemented various lockdown measures which severely impacted migrants, whom lost their jobs due to shutting down of economic activities. Due to this economic slowdown, about 40 million migrant workers of the country are facing the major issues like lack of social security and health benefits, lack of portability of state-provided benefits and lack of social equality. The issue of having uncertainty about the future in the urban cities during total lockdown period led the migrant workers to travel to their hometowns. It is essential to explain the environment of social and economic uncertainty among these industrial workers during the pandemic situation and to bring the attention of the policy makers on the issues facing by the migrant industrial workers amid the COVID-19 pandemic situation.
\end{abstract}

Keywords: COVID-19, Global health crisis, Social and Economic issues, Migrant workers

Suggested Citation: Neetu Jha (2021). Uncertainty among the Migrants during the Lockdown in India. International Review of Social Sciences Research, Volume 1, Issue 2, pp. 18- 33 .

About the author:

Ph.D Scholar, Department of Economics, Punjabi University Patiala 


\section{Introduction}

The COVID-19 crisis for the first time has brought 'invisible' migrants and the phenomenon of migration to the centre stage of policy concern around social protection. Migrant worker tragedy unfolding in the wake of the COVID-19 pandemic lockdown is reinforcing the necessity of consolidating the social policy efforts of the past decades. Migrant workers occupy a special position in the debates around development and social protection. They have driven the engine of globalisation, though not reaped great benefits from the process. The pandemic caused by the coronavirus disease, the gravest health emergency of the century, is poised to disrupt social, economic and political systems and lives worldwide.

In the wake of COVID-19, the very factors that made them desirable as a workforce are turning against them. As millions of migrant workers in India began their long trek home, carrying children, clutching their meagre possessions, crowding disrupted transport networks, beaten and no resources, after the sudden lockdown in the wake of the novel coronavirus pandemic, they faced hunger, destitution, the wrath of the police and suspicion of communities and tragic death (Ghosh, 2020; Jadhav, 2020; Jha \& Pankaj, 2020). The suffering borne by the uprooted informal workers, who constitute more than 90 per cent of India's workforce and have helped to build India's US\$2.9 trillion economy demonstrate the frailty of state social protection systems, the erosion of recent progress and the urgent need for state welfare measures to be more robust and accountable. Unorganised-sector workers and circular migrants working on casual and irregular contracts are emerging as the most vulnerable community and are at great risk.

Internal migrants form a crucial part of India's economy. The Economic Survey 2016-2017 estimated that there are 100 million internal migrants in India, which make up about 20 per cent of the total workforce. They contribute an estimated 10 per cent of India's economic output (Al-Jazeera, 2020) and play an important role in the economy of the country. Many of the internal migrants travel from poorer states such as Bihar and Uttar Pradesh in the north to work in the industrial hubs of more developed states like Gujarat and Maharashtra in the south, or to the metro cities. They depart from remote villages seeking work in large cities to support families whom they usually leave behind. 
This article discusses how poverty, informality and inequality have been accentuated in the context of COVID-19 pandemic through the experiences of the migrant workers in India during the period of pandemic 'lockdown'. It also examines how social policies under changing political regimes and fluctuating economic climates designed protection instruments and how these safety nets can be mobilised by democratic and accountable governance to respond to the crisis of millions of informal workers displaced by COVID-19. Overall, the aim is to discuss the scope of current social policy in India to protect the most vulnerable in the context of dislocation from work, loss of income and livelihoods and the added problems of stigma, discrimination and destitution. For the analysis and discussion, the article draws on sources such as academic articles, policy briefs, government surveys, reports, press notes and advisories and current newspaper and online media reportage of the unfolding health and humanitarian crisis about informal migrant workers. The article argues that the scale and depth of poverty revealed by the COVID-19 migrant issue suggest renewed attention towards the urgency of adequate financial resources to consolidate social protection and democratic governance that demonstrate commitment to protect the basic entitlement and fundamental rights of all, and especially its most disadvantaged citizens.

\section{Discussions}

\subsection{Uncertainty among migrants during COVID-19}

Following the outbreak of the COVID-19 pandemic, a sudden proclamation of the national lockdown (24 March to 31 May), the first phase for 21 days, extended for 19 days, further extended for 15 days and extended again for 15 days starting May 18, to break the chain of transmission of the coronavirus caused panic among millions of migrant workers in India's big cities. As the announcement of lockdown with a notice of less than 4 hours spread, migrant workers were rendered instantly without work. Panic-stricken workers arrived at bus stops and highways in large crowds hoping to reach their distant rural homes. The point of the lockdown measure was to initiate 'social distancing' to prevent the spread of infection. But there was no way that the migrant workers could fulfil those conditions in their temporary, cramped urban homes without work, income or social protection. Their response to the directive for preventive confinement over the next days and weeks exposed the insecurity, uncertainty and precarity of their life and circumstances. At present, 400 million workers in the informal economy, constituting 90 per cent of India's workforce, are at risk of 
falling deeper into poverty. Outraged by the condition of the migrant workers, public policy academics have described the COVID-19 lockdown as 'the choice between virus and starvation (Chen, 2020).

The 'Great Lockdown', had led to a massive collapse in all economic activities, 'the worst economic downturn since the great depression' (Gopinath, 2020). According to a Centre for Monitoring Indian Economy (CMIE) report, India's lockdown order led to a jump in unemployment rate from 21 per cent to 26 per cent in mid-April and a weekly decline in labour market participation (The Economic Times, 2020, April 29). CMIE data show that the unemployment rate increased from 7.03 per cent in May 2019 to 23.98 per cent on 2 May 2020 (CMIE, 2020). Following the lockdown, millions of workers left from industries such as retail, construction, textile, tourism and leather.

On 26 March, Surendra Pandey walked $110 \mathrm{~km}$ to his home when the plywood factory in Lucknow, in the northern state of Uttar Pradesh, downed shutters. There was no transport available, he told press reporters, and kind people helped him with water and food during his inter-state travel. At this point, India had only 600 confirmed coronavirus cases and 13 deaths. A 39-year-old manual worker from the industrial town Surat in the Western state of Gujarat, also walking back home with his 15-year-old son, told reporters that he would have to borrow money to survive. According to trade union reports, 60,000-70,000 people, mainly in domestic service and construction work, left the state of Gujarat for their home state, neighbouring Rajasthan, within days after the lockdown order (Sharma \& Khanna, 2020). From New Delhi, men, women and children walked to neighbouring Uttar Pradesh.

On 27 March, a man working as a welder left the southern state and information technology (IT) hub, Bangalore, to walk home, an impossible $800 \mathrm{~km}$ to Rajasthan. Reporters found him in Tumkur, $70 \mathrm{~km}$ away, where he had reached in 18 hours on foot (Nagaraj \& Srivastava, 2020). Another Reuters story, carried on 21 April, described how a group of 50 construction workers, women and men with small children, walked from the national capital, Delhi, after lockdown, on the midnight of March 24, to their village in drought-affected Bundelkhand in the state of Madhya Pradesh, a distance of nearly $500 \mathrm{~km}$. They reached their village after walking and taking lifts from the occasional truck carrying essential goods. On their journey, they were pushed by the police to keep walking and not 
stop or gather anywhere (Pal \& Siddiqui, 2020). Seasonal labourers in agriculture travel hundreds of kilometres on established routes. In a heartrending episode, a 12-year old tribal girl, who had migrated with a group of women and men from Chhattisgarh to Telangana for chilli harvest, died of dehydration on the way as the group walked back home (Verma, 2020). The immense traumatic incident is the death of 16 migrant workers who were crushed to death by a goods train as they fell asleep exhausted on a railway track after walking for kilometres (Banerjee \& Mahale, 2020).

Migrants began fleeing the cities out of fear of COVID-19 infection. They left on foot due to transport lockdown. Due to the long period of lockdown, migrants preferred to leave for rural homes because they lacked the economic means to support themselves and selfisolate in urban areas. The initial government response to prevent migrant movement towards their homes was informed by the fear that they would carry the contagious coronavirus to their hometowns and villages leading to community transmission of the COVID-19. Thus, migrants were not allowed to leave the city. When the Government of India (GOI) went to the Supreme Court to clarify why migrants could not leave their destination cities, the Apex Court had asked the central government to ensure the provision of food, water and shelter for the migrants (Bindra \& Sharma, 2020). Health experts had questioned the assumption that most migrants were likely to be COVID-positive. Later, the state governments were tasked with the responsibility of arranging quarantine for all returning migrants and providing them with health services if required. On 23 April, news reports estimated that 34 per cent of all COVID-positive cases (out of 4,281 cases from 284 districts) were from the 31 high inmigration districts in the country, based on the economic survey of 2016-17 (Kaushik, 2020).

A situation of insanitary conditions was reported from many areas. Many migrant workers belonging to socially deprived communities faced discrimination. A family in a Bihar village where a migrant worker had returned was not allowed to access their own food stores and take water from the communal hand pump and was forced to depend on water used by cattle (Agrawal, 2020). The return of migrant workers has led to social tensions in many states, and reports of violent clashes among villagers have come up from many places. A youth was beaten to death in Madhaul village in Sitamarhi district on 29 March 2020, after he alleged that two migrant workers had returned to the village from Mumbai without taking any tests. In another incident, angry villagers in Jehanabad district of Bihar assaulted a team 
of officials who had gone to a village to detain migrant workers and put them in a quarantine centre (Manoj, 2020).

These incidents lead to the question "Why did the corona pandemic that requires a health and humanitarian response become an issue of policing or community surveillance?" Security forces are commanded onto the streets as agents of welfare. Police are mobilised as the protectors of public health, the enforcers of social distancing. States are justifying intensified surveillance as a public safety measure (Bhattacharya \& Dale, 2020).

Health systems in many migrant home states are poor, and some migrants could be asymptomatic carriers of the virus. But none of these factors are dependent on the migrants' own actions. Yet, the blame for contracting the disease and the responsibility for doing something about it seems to be overwhelmingly borne by the migrants themselves. Questions need to be asked about the manner in which pandemic communication has been misdirected towards hate and stigma and has been further warped by infodemic on social media (Sengupta, 2020; UN News, 2020). Community surveillance is merging into vigilantism and violence (Agrawal, 2020), putting the migrant in an anxious and complicated situation. Lack of work has also pushed several thousand migrant workers to the edge of starvation, sparking protests. Daily wage earners or those working on piece-rate wages, with their meagre income, do not have the capacity to stay at the destination without work. Soon after the announcement of the extension of the lockdown in Mumbai, a false rumour about a special train sent thousands of migrants to a sub-urban train station, creating a riot situation (Miglani \& Jain, 2020). These situations underscore not just shortcomings of emergency measures and unpreparedness of local administration but also the challenges of providing relief to millions of unprotected informal workers with no means of subsistence, no homes to practise distancing and receiving confusing information and communication about the ongoing situation.

\subsection{Response towards COVID-19 relief measures}

That the lockdown announcement had huge implications for the economy in general and for the informal migrant labourers in particular was acknowledged and responded to by the government. On $26 \mathrm{March}$, the Indian finance minister announced a relief package for the poor affected by COVID-19. Amounting to US $\$ 22.6$ billion, this would pay for free food grains, liquefied petroleum gas (LPG) for cooking, cash transfers for 3 months and insurance 
for frontline healthcare workers (The Economic Times, 2020). In April, the government announced that 330 million poor people have been assisted through transfers amounting to `312,350 million (USD 4,129 million) under Prime Minister's Poor Relief Scheme (PMGKY) (All India Radio News, 2020); `100,000 million (USD 1,322 million) has been transferred to 200 million women holding special Jan-Dhan accounts ( 500 per person), '14,050 million (USD 186 million) was provided under welfare pension schemes to 28.2 million people, `161,460 million (USD 2,134 million) to 80 million registered farmers under cash income support scheme, PM-KISAN, and `34,970 million (USD 462 million) worth of financial support to 21.7 million building and construction workers. Under the PMGKY, 392.7 million people received free food grains, and 26.6 million LPG cylinders were distributed under the PMUY scheme (All India Radio News, 2020). However, an assessment by the International Monetary Fund (IMF) shows that overall support by the central and state governments through various cash and kind transfers and other measures, such as healthcare infrastructure, testing facilities and tax relief, was only about 0.2 per cent of India's GDP (IMF Policy Tracker).

Critics argue that these disbursements are part of regular welfare dues to eligible groups and do not address the new catastrophic losses, such as that of incomes, leading to ongoing survival crises suffered by stranded and out-of-work migrant informal workers. The government, they claimed, was dressing up the small, targeted transfers as a special package for COVID-19 (Bajaj et al., 2020). These transfers amounted to less than 0.8 per cent of the GDP and only 5.6 per cent of the central government's planned financial outlay for 2020-21. Cash transfers to Jan-Dhan accounts amount to less than `17 (USD 0.22) per household and 4 (USD 0.05) per person per day (Bajaj et al., 2020). Moreover, migrant workers unable to return home and those who are not ration card holders at the destination would not benefit from additional free food grains under the PDS. They cannot avail increased MGNREGA (public works) wages until they go back home and the lockdown is over. Besides, GOI continues to use outdated 2011 data to distribute food under the National Food Security Act. Dreze (2020, April 9) recommends the use of the projected 2020 census figures to design the relief package. The PMJDY list for cash transfers would exclude poorer women. As the majority of the seasonal migrants are landless or marginal farmers, they will not be benefitted from the grant to landholders under schemes such as PM-KISAN through which the central 
government provides an income support of `6,000 (USD 79) a year to farmers in three equal cash transfers of `2,000 (USD 26) every 4 months.

Similar is the case with benefits under the Building and Other Construction Workers Welfare Board (BOCWWB). Registration under the statutes requires 90 days of work in the previous year. Also, most states do not register migrants, and registration is not portable. Further, the number of BOCWWB-registered workers is only 35 million in the whole country (The Economic Times, 2020, March 27). An alternative suggestion was a Union bank of India (UBI)-type transfer that would include stranded workers, amounting to an income support based on the current national floor wage of approximately `200 (2.6 USD) per day for the period of the lockdown (The Economic Times, 2020, March 25).

The 2019 Nobel laureate economist Abhijit Bannerjee argues that the Indian government needed to support the poor (Biswas, 2020). The emergency situation created by the COVID- 19 lockdown and the uncertainty about the future trajectory of the pandemic requires immediate and near universal cash transfers to the poor (Biswas, 2020). Instead of narrow targeting and searching for beneficiaries or establishing 'deservingness', the government should use a consolidated list of beneficiaries of all welfare schemes to make immediate transfers (Biswas, 2020; Somanchi \& Khera, 2020). Beyond standard welfare measures, the COVID-19 pandemic requires disaster-grade response, and the government issued directives under the appropriate law, the National Disaster Management Act, to support key decisions. Using a section of the National Disaster Management Act (NDMA), 2005, the Ministry of Home Affairs (MHA) issued a number of advisories to state governments, including order for restricting the movement of migrants along with the provisions that must be made for them (Ministry of Home Affairs, March 29, April 3). State governments were tasked with providing temporary shelters with basic amenities for migrants who remained in destination areas, return migrants were to be kept in quarantine for 14 days in home states, landlords were asked to defer rents for migrants, and employers were asked to give them wages for the period of the lockdown.

A critical gap has been the absence of adherence to minimum standard of relief (including provision of food, water, shelter and sanitation) and compensation for loss of life and livelihood that must be provided to affected persons under the disaster management law (Sibal, 2020). The government has also transferred significant responsibility of disaster relief 
to states and private enterprise owners, whereas the NDMA (2005) requires the central government to take some financial liability for immediate disaster relief. Activists and volunteers have raised alarm about the abysmal conditions in the temporary shelters where migrants are confined (Roy Burman, 28 April 2020).

The Indian government's pandemic response is moving towards technologies and citizen responsibility to stay safe. Automation and contact tracing applications are being used in many countries by governments to trace community transmission of COVID-19 and take decisions about lifting the lockdown measure (The Economist, 2020; Kelion, 2020). Concerns are also being raised about data privacy and providing private parties, technology providers and states with wideranging powers of surveillance over individuals (Soltani, Calo, \& Bergstrom, 2020). The Aarogya Setu Application (ASA) launched by the GOI for the contact tracing of COVID-19-affected people finds itself as a centre of these debates. The ASA is being used to seek a number of additional information, beyond health and travel, and it is being connected to the issue of travel passes (Mehrotra, 2020). The conflation of disease surveillance/monitoring with personal, societal and national security signals the central place of security in government welfare discourse. Migrant workers and people in their rural communities are unlikely to own smartphones. For them, COVID-19 protection would require improved and free healthcare services, water and sanitation access and support in the form of frontline health workers to monitor the health and well-being of return migrants and home communities through the period of quarantine and in days to come. Reliance on technology must be combined with, and not replace, measures that directly aid the well-being of informal workers and their home destination communities.

In his address to the nation on 12 May, the Indian Prime Minister Narendra Modi announced an economic package worth `20 trillion (USD 264.08 billion), with the intended aim to make India self-reliant in the post COVID-19 world. He described this intervention as a movement towards self-reliant India ('Atmanirbhar Bharat Abhiyan'). This was followed by a five-phased announcement by the finance minister who emphasised 'land, labour, liquidity and laws' as vital aspects of this package. The announcement of free food grain supply (5 $\mathrm{kg}$ of grains per person and $1 \mathrm{~kg}$ of chickpeas per family) for 2 months to 80 million migrant workers without a ration card, outside the ambit of National Food Security Act, was expected to provide some relief to migrant workers. The new provisions also 
promised an additional allocation of USD 5.286 billion for the public works programme MGNREGA that is expected to generate 3 billion person-days of work to address the subsistence needs of out-of-work migrants returning to rural areas. Observers have pointed out that the COVID-19 relief package continues to fall short of expectations as it includes previously announced fiscal and monetary measures. The additional measures in the recent announcement amount to only 2.7 per cent of the GDP as relief for businesses and not more than 1.1 per cent of the GDP as a safety net for poor households, migrants and farmers (IMF, 2020). Thus, as COVID-19 cases travel with the tired migrants to their rural homes, government social protection measures resemble a drop in an ocean of trouble.

\section{Conclusion}

When large-scale population migration occurs as a direct result of a health crisis, the movement mostly tends to be internal, temporary and early on in the health crisis. It generally happens to regions directly outside the immediate crisis zone, and mostly happens because of misunderstandings and panic, including financial crisis or fear of losing job. During the 2003 SARS outbreak, up to 1 million people left Beijing. In such example, people tended to go back to their native villages and return to the city after the crisis had subsided. A pneumonic plague broke out in Surat in August 1994, and receding that was a bubonic plague in Maharashtra's Beed district. Compared to its bubonic form, the pneumonic plague spreads rapidly, and the plague in Surat caused widespread panic. The outbreak of the disease led to more than 200,000 people fleeing the city, making it one of the largest post-independence migrations in the country (Leo, 2020). Bihari workers fled from Maharashtra some years ago, when hostile nativists turned against them. Similarly, racial hostility spread panic among migrants from the North-East living in Bangalore in 2016.

Whether it is economic recession or an epidemic like COVID-19, migrant workers in large cities are forced either to stay in perilous conditions in the urban areas, or go back to their places of origin- villages or smaller towns. Initially, they change from becoming providers of remittance incomes to their households, to becoming dependents of these households. Many of these migrant workers come from the most depressed and backward regions of the country, where there is currently little potential for employment and education (Kumar et al., 2009). In this way, any health or economic crises at the destination also increase return migration to origin communities (Castles, 2011). 
Another major challenge raised by the pandemic could be on the food security and nutrition. The COVID-19 may bring hunger to millions of people around the world. Available evidence suggests that insecurity is one of the main reasons why people abandon their livelihoods and move to other places. Crisis increases food insecurity and limits the livelihood options of migrant populations. On the one hand, lockdowns and social distancing measures are drying up work and incomes, whereas they are likely to disrupt agricultural production, transportation systems and supply chains on the other. According to the United Nation's World Food Programme (WFP), an estimated 265 million people could be pushed to the brink of starvation by the end of year 2020 (Dahir, 2020). India is one among the countries where child undernutrition is severe. Around 38.4 per cent, 21 per cent and 35.7 per cent of children below 5 years suffer from stunting, wasting and underweight, respectively. Malnourishment results in compromised immunity, which puts an individual with a greater risk and susceptible to the spread of the virus. Undernutrition is a major underlying cause of child mortality in India, as it is the primary reason behind 69 per cent of deaths of children below the age of 5 in India (UNICEF, 2019).

Contemporary theories of migration suggest that decisions to move or stay and the overall patterns of movement are closely related to economic conditions in places of destination and origin, relationships that connect people between origins and destinations and the accumulated experiences at destinations among individuals and members of their community (Haas, 2012). Evidence from the Asian Financial Crisis and the Global Economic Crisis indicates that migrants' cumulative experiences and shared migrant associations might influence the propensity for migrants to return to origin after an economic tremor (Curran et al., 2016). A number of migrant workers who left the big cities during the crisis may never return, preferring to drag out a living on their marginal farms or find work in nearby towns. It would deprive industrial centres such as Delhi, Gurugram, Surat and Tiruppur, Mumbai, etc. of labour for a long period of time, resulting in temporary shortage of human resources in the industries.

An epidemic is a problem that tests the ability of a nation to effectively protect its population, to reduce human loss, to save the economy and to rapidly recover (Rachaniotis et al., 2012). The Central and State governments are preparing strategies to cope with the crisis. The states and union territories have also been advised to make these vulnerable groups 
aware of measures taken by the government, including provision of free food grains and other essential items through public distribution system (PDS), and streamline the procedures. The Union government is planning to give unemployment benefits to a section of organised workers who may lose their jobs due to the COVID-19 pandemic. The labour and employment ministry is looking to extend the scheme and allow workers to avail unemployment insurance if they are impacted by coronavirus (Jha, 2020). However, these measures are not sufficient considering the intensity of the crisis. Much more can be done by the government to protect its people and economy.

The coronavirus epidemic has come with extraordinary, intense uncertainty. It is difficult to estimate how long and to what extent will the impact of the epidemic be on the lives of people and economy of the country. The government has to come up with a wellcrafted strategy to deal with this crisis. At the national level, greater coordination is required between government agencies separately tasked with migration and health mandates. There is also a need to relook at the national migration policies, which should accommodate the assistance and protection of migrants arriving from, or faced with the prospect of returning to, the areas affected by health crises. Establishment of resilient food systems could reduce food insecurity and the pressure to return to origin among migrants. More research is required on the impact of health crises on migration, particularly in distinguishing health from other motivations to migrate.

\section{References}

Agrawal, P. (2020). Bihar's migrants return to face stigma, under-prepared medical facilities. Retrieved from https://www.indiaspend.com/bihars-migrants-return-to-facestigmaunder-prepared-medical-facilities/

Al-Jazeera. (2020, April 2). Hungry, desperate: India virus controls trap its migrant workers. Al-Jazeera. Time. Retrieved from https:// www.aljazeera.com/ajimpact/hungrydesperate-india-virus-controls-trap-migrant-workers-200402031123631. html

Bajaj, A., Datt, G., Lata, G., Islam, A., Jayasuriya, S., Maitra, P., Ray, R. (2020, April 2). Nine concerns about the Centre's 1.7 lakh crore package. Retrieved from https:// thewire.in/government/covid-19-india-government-package 
Banerjee, S., \& Mahale, A. (2020). 16 Migrant workers run over by a goods train near Aurangabad in Maharashtra. Retrieved from https://www.thehindu.com/news/ national/other-states/16-migrant-workers-run-over-by-goods-train-near-aurangabadinmaharashtra/article31531352.ece

Bhattacharya, T., \& Dale, G. (2020). Covid capitalism: General tendencies, possible leaps. Retrieved from https://spectrejournal.com/covid-capitalism

Bindra, J., \& Sharma, N. C. (2020). Coronavirus: Govt tells SC one third of migrant workers could be infected. Retrieved from https://www.livemint.com/news/india/covid-19govt-tells-sc-one-third-of-migrant-workers-could-be-infected-11585643185390.html

Biswas, S. (2020, April 24). Coronavirus lockdown: Nobel prize economist says India must do more for poor. Retrieved from https://www.bbc.com/news/world-asiaindia52403589

Castles, S. (2011). Migration, crisis, and the global labour market. Globalizations, 8(3), 311324.

Centre for Monitoring of Indian Economy (CMIE). (2020). Unemployment rate in India. Retrieved from https://unemploymentinindia.cmie.com/

Chen, M. (2020). To die from hunger or the virus. An all too real dilemma for the poor in $\begin{array}{llll}\text { India and } \quad \text { (elsewhere). } & \text { Retrieved }\end{array}$ https://www.wider.unu.edu/publication/diehunger- or-virus

Curran, S. R., Meijer-Irons, J., Garip, F. (2016). Economic shock and migration: Differential economics effects,

migrant responses, and migrant cumulative causation in Thailand. Sociol Dev (Oakl), 2(2), 119-157. https://doi. org/10.1525/sod.2016.2.2.119

Dahir, A. L. (2020, April 22). Instead of coronavirus, the hunger will kill us. A Global Food crisis Looms. Retrieved from https://www.nytimes.com/2020/04/22/world/africa/coronavirus-hunger-crisis.html

Das, R., \& Kumar, N. (2020). Chronic crisis: Migrants and India’s COVID-19 lockdown. Retrieved from https://blogs.lse.ac.uk/southasia/2020/04/08/chronic-crisismigrantworkers-

and-indias-covid-19-lockdown/

Ghosh, D. (2020, April 27). Coronavirus: Migrant worker who walked two days to get home 
now faces stigma, uncertain future. Retrieved from https://scroll.in/article/957657/ coronavirus-migrant-worker-who-walked-two-days-to-get-home-now-facesstigmauncertain- future

Gopinath, G. (2020). The great lockdown: The worst economic downturn since the great depression. Retrieved from https://blogs.imf.org/2020/04/14/the-greatlockdownworst- economic-downturn-since-the-great-depression/

Government of India. (2016). Spreading JAM across India's economy. Annual Survey Report. Economy Survey. Ministry of Finance. Retrieved from https://www. indiabudget.gov.in/budget2016-2017/es2015-16/echapvol1-03.pdf

Government of India. (2019). Periodic labour force survey 2017-18. Retrieved from http:// Www.mospi.gov.in/sites/default/files/publication_reports/Annual\%20Report\%2C\%20 PLFS\%202017-18_31052019.pdf

International Labour Organisation (ILO). (2020). ILO monitor: COVID-19 and the world of work (2nd ed.). Updated estimates and analysis. Retrieved from https:// www.ilo.org/wcmsp5/groups/public/@dgreports/@dcomm/documents/briefingnote/ wcms_740877.pdf

International Monetary Fund (IMF). (2020). Policy responses to COVID-19 policy tracker. Retrieved from https://www.imf.org/en/Topics/imf-and-covid19/Policy-Responsesto- COVID-19

Jha, M. K., \& Pankaj, A. K. (2020). Insecurity and fear travel as labour travels in the time of pandemic. In R. Samaddar (ed.), Borders of an epidemic: COVID-19 and migrant workers. Kolkata: Mahanirban Calcutta Research Group. Retrieved from http://www. mcrg.ac.in/RLS_Migration_2020/COVID-19.pdf

Kannan, K., Srivastava, R., \& Sengupta, A. (2006). A major national initiative. Economic and Political Weekly, 41(32), 3477-3480. Retrieved June 4, 2020 from Www.jstor.org/ stable/4418556

Kaushik, K. (2020, April 7). One-third of COVID-19 cases from 31 districts that get most migrants. Retrieved from https://indianexpress.com/article/india/coronaviruscasesmigrants- hotspots-6350734/ 
Manoj, C.K. (2020, March 31). COVID-19: Social tension in Bihar over returning migrants. Retrieved from https://www.downtoearth.org.in/news/governance/covid-19- socialtension-in-bihar-over-returning-migrants-70126

Mehrotra, K. (2020, April 21). Aarogya Setu integration ensures high risk people not issued travel e-pass. $\quad$ Retrieved from https://indianexpress.com/article/india/coronavirusaarogya- setu-integration-ensureshigh-risk-people-not-issued-travel-e-pass-6371637/

Miglani, S., \& Jain, R. (2020, April 14). UPDATE 3-India extends world's biggest lockdown, ignites protests by migrant workers. Retrieved from https://br.reuters.com/ article/asia/idUSL3N2C21L1

Ministry of Home Affairs, Government of India. (2020, April 3). On directions of the Prime Minister, Home Ministry approved release of Rs.11092 crores under State Disaster Risk Management Fund to all States. Retrieved from https://pib.gov.in/ PressReleaseIframePage.aspx?PRID=1610756

Nagaraj, A., \& Srivastava, R. (2020, March 27). FEATURE — In locked down India, migrant workers walking home dial for help. Thompson Reuters Foundation. Retrieved from https://www.reuters.com/article/health-coronavirus-india-workers/feature-inlockeddown-india-migrant-workers-walking-home-dial-for-help-idUSL4N2BK2DL

Pal, A., \& Siddiqui, D. (2020, April 21). Special report: India's migrant workers fall through cracks in the coronavirus lockdown. Retrieved from https://in.reuters.com/ article/health-coronavirus-india-migrants/special-report-indias-migrant-workersfallthrough- cracks-in-coronavirus-lockdown-idINKBN2230M4

Roy Burman, S. (2020, April 28). Delhi police report on migrant camps: Fans not working, bad food. Retrieved from https://indianexpress.com/article/india/delhi-policereporton- migrant-camps-fans-not-working-bad-food-6382213/

Sengupta, S. (2020, April 7). How to stir confusion amidst a pandemic: COVID-19 and misinformation on WhatsApp. Economic and Political Weekly, Engage. Retrieved from https://www.epw.in/engage/article/how-stir-confusion-amidst-pandemic-covid-

Sharma, S., \& Khanna, S. (2020). India's migrant workers face long walk home amid coronavirus lockdown. Retrieved from https://www.reuters.com/article/us- 
healthcoronavirus- india-migrant-labo/indias-migrant-workers-face-long-walk-homeamidcoronavirus- lockdown-idUSKBN21D2O0

Soltani, A., Calo, R., \& Bergstrom, C. (2020, April 27). Contact tracing apps are not a solution to COVID-19 crisis. Retrieved from https://www.brookings.edu/techstream/ inaccurate-and-insecure-why-contact-tracing-apps-could-be-a-disaster/

Somanchi, A., \& Khera, R. (2020). COVID-19 and Aadhar: Why the Union Government's relief package is an exclusionary endeavour. Retrieved from https://www.epw.in/ engage/article/covid-19-and-aadhaar-why-union-governments-relief

The Economic Times. (2020, March 25). Covid-19 outbreak: States asked to transfer funds to construction workers accounts. Retrieved from https://economictimes.indiatimes. com/news/politics-and-nation/covid-19-outbreak-states-asked-to-transfer-fundstoconstruction-workers-accounts/articleshow/74802336.cms?from=mdr

The Economist. (2020, April 16). App-based contact tracing may help countries get out of lockdown. Retrieved from https://www.economist.com/science-andtechnology/ 2020/04/16/app-based-contact-tracing-may-help-countries-get-out-oflockdown

The Economic Times (2020, April 29). Unemployment rate improves to $21.1 \%$ from last week's $26 \%$. Retrieved from https://economictimes.indiatimes.com/news/economy/indicators/ unemployment-rateimproves-to-21-1-from-last-weeks-26/articleshow/75437330.cms

UN News. (2020, April 10). COVID-19 threatening global peace and security, UN Chief warns. Retrieved from https://news.un.org/en/story/2020/04/1061502 United Nations Development Programme (UNDP). (2019). New data challenges traditional notion of 'rich' and 'poor'. Retrieved from https://www.in.undp.org/content/india/en/ home/presscenter/pressreleases/2019-MPI-India.html

UNDP (2020). COVID-19 pandemic: Humanity needs leadership and solidarity to defeat the coronavirus. Retrieved from https://www.undp.org/content/undp/en/home/ coronavirus.html

Verma, G. (2020, April 21). 12-year-old walks 100 km, dies just short of Bijapur home. Retrieved https://indianexpress.com/article/india/12-yr-old-walks-100-km-diesjustshort- of-bijapur-home-6371779/ 